Review Article

\title{
AMTSILATI METHOD IMPLEMENTATION IN PESANTREN AL-AQOBAH KWARON JOMBANG
}

Arif Wicaksono

Received: 10.01 .2021

Revised: 11.02.2021

Accepted: 25.02.2021

Abstract

The purpose of this study was to determine the implementation of the amtsilati method at the Al-Aqobah Kwaron Islamic Boarding School, Jombang. This study concludes several points. First, the implementation of the Amtsilati Method at the Al-Aqobah Kwaron Diwek Jombang hut begins with mapping, namely: a) The first year of memorizing the rules of nahwu and sharaf science and understanding the five volumes of the Amtsilati book; $b$ ) The second year of implementing the Amtsilati method when reading a book that has been determined by the ustadz; c) The third year of reading, understanding the content of the yellow book with reference to the Amtsilati method. Second, the obstacle and solution in implementing the amtsilati method to accelerate the ability to read the yellow book at the Al-Aqobah Kwaron Diwek Jombang boarding school is the obstacle that students experience boredom when memorizing and understanding the Amtsilati method because of the different experiences of students before boarding and studying the yellow book. The solution is to add training so that those who are still left behind in the material can catch up with those who already understand giving lessons to those who cannot.

Keywords: amtsilati method, turath, pesantren.

\section{IMPLEMENTASI METODE AMTSILATI DI PONDOK PESANTREN AL-AQOBAH KWARON JOMBANG}

\begin{abstract}
Abstrak
Tujuan penelitian ini adalah untuk mengetahui implementasi metode amtsilati di pondok pesantren al-aqobah kwaron jombang. Penelitian ini menyimpulkan beberapa poin. Pertama, Implementasi Metode Amtsilati di pondok Al-Aqobah Kwaron Diwek Jombang diawali dengan pemetaan yaitu: a) Tahun pertama menghafalkan qaidah ilmu nahwu dan ilmu sharaf dan memahami lima jilid kitab Amtsilati; b) Tahun kedua mengimplementasikan metode Amtsilati ketika membaca kitab yang telah ditentukan oleh ustadz; c) Tahun ketiga membaca, memahami kandungan kitab kuning dengan acuan metode Amtsilati. Kedua, Kendala dan solusi dalam implementasi metode amtsilati untuk mempercepat kemampuan membaca kitab kuning di pondok Al-Aqobah Kwaron Diwek Jombang adalah Kendala para santri mengalami kejenuhan ketika menghafal dan memahami metode Amtsilati karena pengalaman santri yang berbeda sebelum mondok dan belajar kitab kuning. Solusinya adalah penambahan latihan supaya yang masih tertinggal materi bisa menyusul yang sudah faham memberi pengajaran kepada yang belum bisa.
\end{abstract}

Kata kunci: metode amtsilati, turath, pesantren. 


\section{Pendahuluan}

Metode amtsilati yang diterapkan di pondok Al-Aqobah merupakan metode yang menawarkan belajar kitab kuning enjoi dan cepat.Membaca kitab kuning dengan metode ini dapat dikuasai selama enam bulan. ${ }^{1}$ Pada kenyataannya banyak alumni pesantren yang tidak bisa membaca kitab kuning meskipun sudah lama nyantri dipesantren. Salah satu alasannya adalah karena terlalu banyak mata pelajaran yang wajib dipelajari, juga karena kurang minatnya santri untuk belajar kitab kuning yang terkesan sulit dan banyak yang harus dihafal pada hal sumber keilmuan agama islam banyak yang bersumber dari kitab kuning. Fenomena ini akhir-akhir ini sudah kerap terjadi sehingga mengusik pemikiran kita. Karena kurang dengan minimnya peminat mempedalam kajian kitab kuning dapat mengikis kelestarian ilmu agama islam. Pesantren dianggap mampu untuk melestaikan keilmuan agama islam melalui regenerasi alim ulama karena karakter pendidikan di pesantren memberikan nilai tentang etika islam tentang belajar yang merupakan fondasi penting bagi bangunan intelektualisme santri. Pertama, relasi kiyai dengan santri permanen sepanjang hayat.Kiyai tidak hanya dipandang hanya sebagai sumber ilmu pengetahuan tetapi juga sebagai keteladanan moral yang jadi rujukan.Dalam konteks dunia pendidikan di Indonesia sekarang ini pola relasi antara guru dan murid sudah mulai tergerus karena munculnya sumber-sumber ilmu yang bersifat impersonal. Kedua, ajaran tentang belajar dan mencari ilmu yang dipandang sebagai bagian tugas kemanusiaan.

Tetapi yang terjadi di pondok-pondok pesantren khususnya pondok pesantren yang modern dimana materi pelajarannya ditambah dengan kuikulum dari pemerintah maka disamping Ilmu Nahwu dan Ilmu Sharaf ini membosankan juga sulit.Hal ini membuat para santri malas untuk belajar Ilmu Nahwu dan Ilmu Sharaf. Maka perlu adanya perubahan metode ajar untuk menarik minat santri untuk belajar Ilmu Nahwu dan Ilmu Sharaf.

Salah satu strategi belajar mengajar memilih dan menerapkan dan prosedur, metode dan teknik belajar mengajar yang dianggap paling tepat dan efektif. Metode atau teknik penyajian untuk memotivikasi anak didik agar mampu menerapkan pengetahuan dan pengalamannya untuk memecahkan masalah, berbeda dengan cara atau metode supaya anak didik terdorong dan mampu berfikir bebas dan cukup keberanian untuk mengemukakan pendapatnya sendiri. Perlu difahami bahwa suatu metode mungkin hanya cocok dipakai untuk mencapai suatu tujuan tertentu. Jadi dengan sasaran yang berbeda, guru hendaknya jangan menggunakan teknik penyajian yang sama. Bila beberapa tujuan ingin diperoleh, maka guru

${ }^{1}$ Wawancaa dengan Ustadz Nasrul tenaga pengajar amtsilati di pondok Al-Aqobah tanggal 15 maret 
dituntut memiliki kemampuan tentang penggunaan berbagai metode atau mengombinasikan beberapa metode yang relevan. ${ }^{2}$ metode suatu pembelajaran penting untuk membangkitkan minat siswa atau santri untuk semangat belajar yang mana penelitian ini akan dikaitkan dengan cepat bisa membaca kitab kuning dengan metode amtsilati.

\section{METODE PENELITIAN}

Metode yang digunakan dalam peneliti ini yaitu metode penelitian kualitatif lapangan. Pengumpulan data dilihat dari sumbernya ada 2 sumber, yaitu: sumber data primer dan sumber data sekunder. Data primer adalah sumber data yang langsung memberikan data/informasi kepada pengumpul data. Sumber data primer dalam penelitian ini dapat diperoleh dari: Pengasuh Pondok; Ustadz; Pengurus Pondok; dan Santri. Sumber data sekunder adalah sumber data yang tidak langsung memberikan data kepada pengumpul data, misalnya lewat dokumen atau lewat orang lain. ${ }^{3}$ Merujuk pada penjelasan diatas dalam penelitian ini yang termasuk data sekunder adalah dokumen dan arsip kenaikan lulusan setiap tahun di Pondok Pesantren Al-Aaqobah Kwaron Diwek Jombang.

Teknik Pengumpulan Data penelitian ini menggunakan tiga teknik, yaitu Observasi, Wawancara, dan Dokumentasi. Adapun data yang hendak dihimpun melalui observasi ini berkaitan dengan persoalan yang penulis teliti dari sumber data yang penulis jumpai selama mengadakan observasi, ${ }^{4}$ dengan mengamati secara langsung objek dan subjek penelitian tentang Implementasi Metode Amtsilati Untuk Mempercepat Kemampuan Membaca Kitab Kuning Di Pondok Pesantren Al-Aqobah Kwaron Diwek -Jombang. Adapun yang akan peneliti wawacarai adalah kepala madrasah, wakil kepala madrasah, guru dan peserta didik. Responden dalam wawancara ini dilakukan secara purposive sampling, yaitu dipilih dengan pertimbangan dan tujuan tertentu. ${ }^{5}$ pertimbangan tersebut ialah responden yang memiliki kriteria $3 \mathrm{M}$ yaitu mengetahui, mengalami dan memahami. Metode dokumentasi ini dipergunakan untuk memperoleh data tentang gambaran umum sekolah dan bahan tulisa yang berkaitan dengan implementasi metode amtsilati untuk mempercepat kemampuan membaca kitab kuning di Pondok Pesantren Al-Aqobah Kwaron Diwek -Jombang.

\section{Pemetaan Kemampuan Membaca Kitab Kuning Santri}

\footnotetext{
${ }^{2}$ Syaiful Bahri Djamarah, Strategi Belajar Mengajar, Jakata. PT RINEKA CIPTA.2006 hal.7

${ }^{3}$ Sugiyono, Memahami Penelitian Kualitatif ( Bandung: Alfabeta, 2012) hal.62

${ }^{4}$ Suharsimi. Arikunto, Prosedut Penelitian Suatu Pendekatan Praktik ..... hal 272

5 Sugiono, Metode Penilitan Pendidikan: Pendekatan Kuantitatif, Kualitatif dan R\&D (Bandung:
} Alfabet, 2010) hal .300 
Kemampuan yang dimaksud dalam penelitian ini adalah kemampuan membaca kitab kuning. Membaca berarti mengeja atau melafalkan apa yang tertulis. Juga dapat diartikan dengan melihat serta memahami isi dari apa yang tertulis (dengan melisankan atau hanya dalam hati). Sedangkan Kitab kuning merupakan istilah khusus yang digunakan untuk menyebut karya tulis bidang keagamaan yang ditulis dengan huruf arab. Adapun kitab yang digunakan sebagai sumber belajar di pesantren atau pendidikan Islam Tradisional semacamnya disebut kitab kuning.

Pengasuh pondok pesantren al-Aqobah Kwaron Diwek Jombangmemandang bahwa belajarnya santri saat ini terhadap kitab kuning jauh berbeda dengan santri dahulu yang tujuan belajar di Pesantren yang penting mengaji Kitab Kuning, sedangkan santri saat ini selain bisa mengaji juga dituntut untuk sekolah dalam rangka memperdalam ilmu umum.Maka dari itu pihak pengasuh dan ustadz (guru) koordinator dan jajarannya memutuskan memilih metode yang tepat untuk santri supaya tetap bisa mengaji kitab kuning disamping mereka juga harus sekolah. Diantara sekian banyak metode membaca kitab kuning pondok pesantren al-Aqobah Kwaron Diwek Jombangmemilih metode Amtsilati sebagai metode unggulan bagi santri untuk mempercepat kemampuan membaca kitab kuning.

Dalam paparan data disini peneliti mewawancarai Ustadz Akhmad Kanzul Fikriadalah sebagai ketua yayasan serta pengasuh pondok pesantren al-Aqobah Kwaron Diwek Jombangdan Ustadz Nasrullah adalah tutor pengajian Amtsilati yaitu :

Kemampuan Santri dalam membaca kitab kuning yaitu :Telah bisa membaca tulisan arab yang berharakat, kemudian memiliki pengetahuan dari segi kaidahnya, seperti fail, maf'ul bih, mubtada dan khabar. Dalam bahasa arab terdiri dari tiga unsur yaitu isim, fi' il dan huruf, setelah ketiga komponen tersebut dikuasi nahwu dan shorof sebagai acuan membaca, serta mampu menunjukkan dalilnya. jadi itulah kategori santri bisa dan mampu dalam membaca kitab kuning, santri bisa faham dan bisa menerangkan serta menguasai kitab yang telah dipelajari dengan berpedoman pada kaidah ilmu nahwu dan shorof yang telah dihafalkan. ${ }^{6}$

Menurut penuturan dari Ustadz Nasrullah:

Santri bisa membaca kitab kuning yaitu:Mampu dalam melafalkan tulisan arab dan menerjemah dengan tahap pertama yaitu tulisan arab yang berharakat, kemudian mampu menerjemah dan menerangkan serta menjelaskan arti kandungan tulisan yang ada di dalam isi kitab dengan berpedoman pada kaidah ilmu nahwu dan shorof yang telah dihafalkan, tahap selanjutnya adalah mampu membaca dengan tulisan yang gundul (tidak berharakat) hanya ada tanda titik dan koma, karena dalam hal ini kebanyakan kitab kuning tidak berharakat maka kemampuan dalam melafalkan dengan harakat asli yang benar merupakan kemampuan membaca yang bagus. ${ }^{7}$

\footnotetext{
${ }^{6}$ AkhmadKanzul Fikri, wawncara (Pondok Pesantren Al-Aqobah, 23 Agustus 2017)

${ }^{7}$ Nasrullah, wawancara (Pondok Pesantren Al-Aqobah, 23 Agustus 2017).
} 
Hal ini sesuai dengan pengamatan peneliti yakni pembelajaran kitab kuning di Pondok Pesantren Al-Aqobah Kwaron Diwek Jombangpada tahun pertama santri wajib hafal dan faham nahwu dan sharaf dengan menggunakan metode Amtsilati, tahun keduan santri mampu membaca kitab secara sorogan para santri sudah mampu membaca kitab dengan tanpa harokat serta mampu menyebutkan dalil nahwu dan sharafnya yang telah mereka hafal dan fahami di tahun pertama dan tahun ketiga para santri mengaji bandongan dengan kiyai dan ustadz senior untuk memperdalam kajian kitab kuning sehingga mereka dapat menjelaskan isi kitab yang dibaca serta mulai diberi kesempatan untuk mengajar metode amtsilati di kelas tahun pertama. Di tahun ketiga mereka mulai belajar memahami isi kitab kuning tetapi mereka pun masih harus menjaga hafalan nahwu sharafnya karena kyai dan ustadz sesekali sekempatan bertanya tentang nahwu sharaf dan santri selain menjawab juga harus bisa menyebutkan dalilnya. ${ }^{8}$

Kemampuan Santri Pondok Pesantren Al-Aqobah Kwaron Diwek Jombang yakni:

Tahun pertama santri wajib hafal dan faham nahwu dan sharaf dengan menggunakan metode Amtsilati. Sudah jadi sesuatu yang maklum bahwa jika seorang santri yang hendak memahami kitab kuning maka harus menguasai ilmu nahwu terlebih dahulu agar bisa mengetahui kedudukan sebuah kalimat. Hal ini sesuai dengan yang dikatakan oleh M. Sholihuddin Shofwan bahwa ilmu nahwu adalah ilmu tentang qaidah-qaidah yang diambil dari kalam arab untuk mengetahui hukum-hukum kalimat arab, ketika tidak disusun seperti panggilan, idghom, membuang dan mengganti huruf dan keadaan kalimat ketika ditarkib seperti i'rab dan mambi. ${ }^{9}$ Tidak kalah pentingannya santri juga harus menguasai ilmu sharaf sebelum belajar memahami kitab kuning untuk memahami macam-macam perubahan bentuk kalimat karena ada makna yang dikehendaki. Sebagaimana dituturkan oleh M. Abdul Manaf Hamid bahwa ilmu sharaf adalah ilmu yang membahas tentang perubahan kalimat ke kalimat yang lain yang berbeda-beda karena menghendaki makna yang berbeda-beda ${ }^{10}$.

Tahun kedua santri mampu membaca kitab secara sorogan para santri sudah mampu membaca kitab dengan tanpa harokat serta mampu menyebutkan dalil nahwu dan sharafnya yang telah mereka hafal dan fahami di tahun pertama dan tahun ketiga para santri mengaji bandongan dengan kiyai dan ustadz senior untuk memperdalam kajian kitab kuning sehingga mereka dapat menjelaskan isi kitab yang dibaca serta mulai diberi kesempatan untuk mengajar metode amtsilati di kelas tahun pertama. Metode sorogan merupan tindak lanjut setelah santri

\footnotetext{
${ }^{8}$ Arif Wicaksono, Observasi (Pondok Pesantren Al-Aqobah, 23 Agustus 2017).

${ }^{9}$ M. Sholihuddin Shofwan...... hal.11

${ }^{10}$ M. Abdul Manaf Hamid. Pengantar ilmu sharaf lughawi dan istilahi.Nganjuk. P.P FATHUL MUBTADIIN.Hal.7
} 
sudah menguasai ilmu nahwu dan sharaf maka selajutnya mereka memeraktikkannya dengan metode sorogan hal ini sesuai dengan yang dinyatakan oleh M. Fathurahman dan Sulistyoroni bahwa metode pembelajaran dengan pola sorogan dilaksanakan dengan cara santri mengajukan kitab dan membacanya dihadapan kyai, apabila ada keselahan langsung dihadapan kyai. Metode ini hanya dilakukan oleh santri yang khusus memiliki kepandaian lebih. Disinilah santri bisa dilihat kemahirannya dalam membaca kitab dan menafsirkannya ${ }^{11}$.

Tahun ketiga santri mulai memahami isi kitab kuning dengan mengaji bandongan kepada kyai dan ustadz senior. Mereka pun masih harus menjaga hafalan nahwu sharafnya karena kyai dan ustadz sesekali sekempatan bertanya tentang nahwu sharaf dan santri selain menjawab juga harus bisa menyebutkan dalilnya.

Dengan target konsentrasi dan metode Amtsilatidi atas, santri Pondok Pesantren AlAqobah Kwaron Diwek Jombang mampu untuk mencapai target pembelajaran khususnya kitab kuning. Target tersebut antara lain; (a) Santri mampu menghahafal, memahami dan menerapkan ilmu Nahwu dan Sharaf pada tahun pertama yakni santri kelas 7 SMP dan kelas 10 SMA; (b) Pada tahun kedua yakni ketika mereka kelas 8 SMP dan kelas 11 SMA Santri mampu membaca dan menerjemahkan kitab kuning, mampun menerangkan nahwu sharafnya dan menyebutkan dalilnya; (c) Pada tahun ketiga yakni ketika mereka kelas 9 SMP dan kelas 12 SMA santri mampu memahami ibarat yang ada di kitab kuning dan santri juga mampu mengajarkan kemampuannya kepada orang lain.

Dengan demikian hal ini sesuai dengan pendapat Matsuhu yakni bahwa indicator Ketepatan dalam membaca kitab kuning didasarkan atas kaidah-kaidah nahwiyyah dan sharfiyah, Pemahaman mendalami isi bacaan, Dapat mengungkapkan isi bacaan, Setelah santri mampu membaca dengan tepat, santri diminta untuk mengungkapkan dan menjelaskan isi bacaan dengan bahasa sendiri. Karena idealnya mampu membaca kitab kuning disertai juga mampu mengungkapkan isi bacaan. ${ }^{12}$

\section{Implementasi Pembelajaran Metode Amtsilati}

Implementasi metode Amtsilati merupakan program pembelajarannahwu dan sharafyang telah ditetapkan pondok pesantren al-Aqobah Kwaron Diwek Jombang. dengan

\footnotetext{
${ }^{11}$ M. Fathurahman dan Sulistyoroni. ImplementasiManajemen Mutu Pendidikan Islam.Yogyakarta.Teras.2012 Hal.247

${ }^{12}$ Mastuhu, Dinamika Sistem Pendidikan Pesantren, (Jakarta INIS, 1994), hlm. 144.
} 
harapan agar santri lebih aktif dalam proses pembelajaran nahwu sharaf sehingga akhirnya santri mampu membaca dan memahami kitab kuning.

Berdasarkan observasi peneliti, pada santri tahun pertama yakni kelas 7 SMP dan kelas 10 SMA yang bukan alumni metode Amtsialati diajarkan setiap ba'da ashar pukul 16.00-17-00 dan ba'da shubuh pukul 05.00-06.00 pada tahap ini santri diharuskan untuk menghafalkan kitab khulashah satu jilid dan menghatamkan kitab Amtsilati lima jilid. Selain dua waktu tersebut ada waktu setelah magrib pukul 18.30-19.30 digunkan untuk mengaji Al-Qur'an dengan model kelompok. Ketika mengaji Al-Qur'an mereka disuruh untuk menerapkan nahwu sharaf metode Amtsilatiyang dibimbing oleh ustadz Nasrullah.Disamping itu setiap hari setelah azan sampai iqamah dan setelah selesai shalat maktubah seluruh santri membaca dan menghafalkan kitab khulashah bersama-sama setiap hari ${ }^{13}$.

Tahun kedua yakni kelas 8 sampai 9 SMP, kelas 10 SMA alumni dan kelas 11 SMA pada tahap mereka sudah tuntas mempelajari Amtsilati dan tuntas menghafal kitab khulashah ba'da magrib pukul 18.30-19.30 mereka belajar kitab Taqrib kepada ustadz Imam Fauzi, sedangkan kelas 11 SMA yang bukan alumni mereka setor hafalan kitab Arba'inNawawi kepada ustadz Akhmad Kanzul Fikri. dengan menggunakan metode sorogan dalam model kelompok (halaqoh) dengan jenjang kemampuan yang sama, dengan tujuan santri yang sudah melewati tahap awal yakni tahun pertama dapat menerapkan nahwu sharaf yang telah mereka hafal dan mereka pelajari sehingga mereka mampu menguasai gramatikal arab pada kitab kuning. kemudian seorang ustadz atau guru mengucapkan salam terlebih dahulu sebelum memulai pembelajaran, setelah itu ustadz memulai menunjuk satu persatu santri untuk membaca kitab yang mana makna dan i'robnya para santri mencari sendiri ketika di kamar sebelum pengajian dimulai. Dalam hal ini sesekali ustadz bertanya tentang nahwu sharafnya serta meminta menyebutkan dalil kepada santri yang telah ditunjuk.

Untuk tahun kedua ini ba'da ashar, ba'da magrib dan ba'da shubuh mereka mengaji bandongan kepada kiyai dan ustadz senior. Pada tahun ketiga mereka mengaji kitab kuning dengan metode bandongan, sorogan dan tanya jawab kepada kiyai dan ustadz senior setiap ba'da ashar pukul 16.00-17.00, ba'da magrib pukul 18.30-19/30 dan ba'da shubuh pukul 05.0006.00. Materi kitab yang dikaji adalah dengan meggunakan kitab yang lebih tinggi lagi yakni antara lain Risalah Ahlu Sunah, Riyadhushalihin Dan Nashaihul Ibad. Pembelajaran kitab yang di ampu dengan mebacakan di depan santri (bandongan), setelah itu ustadz membacakan terjemahan kitab kata per kata beserta dengan penjelasan isinya, kemudian santri mendengarkan

${ }^{13}$ Arif Wicaksono, Observasi (Pondok Pesantren Al-Aqobah, 22Agustus 2017). 
penjelasan dari ustadz, memaknai kitabnya dan membuat catatan-catatan kecil. Sebelum ustadz mengakhiri pembelajaran ustadz biasanya menyuruh santrinya untuk membaca kembali kitab yang telah dibacanya tadi dengan cara perorangan (sorogan)serta bertanya tentang nahwu sharafnya juga menyebutkan dalilnya yang telah mereka hafal pada tahun pertama.Serta jika waktu tidak mencukupi ustadz akan menyuruh santrinya untuk mengulang membaca kitabnya pada hari berikutnya.dan pelajaran tersebut diakhiri dengan berdoa dan salam sebagai penutup.

Dalam kesempatan yang sama peneliti juga melakukan observasi kaitannya dengan pelaksanaan program pembelajaran yang mana menggunakan metode sorogan dari mulainya kegiatan sampai selesai. Bahwasanya penggunaan metode sorogan tidak digunakan di dalam kegiatan belajar-mengajar saja tapi berlanjut setelah selesai kegiatan program selesai.Santrisantri disuruh mengulang kembali bacaan kitab yang telah dibacakan Ustadz yang dipelajari menggunakan metode sorogan dimana santri yang belum lancar akan disuruh mengulang terus bacaanya sampai lancar. Pukul 20.00-21.00 santri belajar mandiri bila tidak tahu tentang arti atau bacaan kitabnya kurang lancar santri akan menanyakan pada temannya yang lebih paham. Pada kesempatan lain santri berdiskusi atau musyawaroh kelompok yang dipimpin oleh Rois atau santri yang lebih paham tentang mata pelajaran yang telah dipelajari.

Pelaksanaan kegiatan program belajar yang dilakukan ba'da isya menggunakan metode sorogan untuk mengulang kembali bacaan, murod (penjelasan) dan tarkib (susunan) i'rob kitab kuning yang telah dipelajari pada saat kegiatan mgaji bandongn.Di sini santri-santri dikelompokan kedalam beberapa kelompok yang masing-masing kelompoknya terdiri dari 1-3 santri. Tahapan pelaksanaan metode sorogandilaksanakan dengan menggunakan metode halaqoh, bandongan, diskusi, dan musyawarah. Secara berurutan tahapannya adalah sebagai berikut. Santri duduk di sekitar ustadz secara melingkar maupun duduk secara teratur. Ustadz membuka pembelajaran dengan mengucapkan salam dan kemudian berdoa. Ustadz memberikan motivasi untuk menumbuhkan semangat belajar santri. Mengulang pelajaran kemarin dan menambah keterangan jika penjelasan dari ustadz sulit dipahami oleh santri. Ustadz membacakan kata per kata dari isi kitab kemudian santri memaknai kitab dan membuat catatancatatan kecil dari penjelasan yang diberikan ustadz. Ustadz memberikan beberapa pertanyaan kepada santri. Ustadz akan menyuruh santrinya maju satu persatu untuk maju membaca , menerangkan. Dan menjelaskan pelajaran apa yang dibaca dan dijelaskan oleh Ustadz. Ustadz menyimak, mendengarkan dan memperhatikan bacaan santri dan mengevaluasi bacaan santri. Bila mana terdapat kesulitan pada saat membaca kitab, teman sejajar adalah sebagai penanggung 
jawab dan membantu kesulitan santri pada saat maju di depan. Ustadz meminta Kesimpulan dari bab kitab yang dipelajari, dan selalu berpesan untuk menyiapkan persiapan membaca kitab keesokan harinya. Salam penutup ${ }^{14}$. Dari paparan diatas penerapan metode Amtsilatidi Pondok Pesantren al-Aqobah Kwaron Diwek Jombang sudah terbilang efektif apalagi jika ditunjang dengan menerapkan metode yang lain. Di Pondok Pesantren al-Aqobah Kwaron Diwek Jombangsendiri tepatnya pada sistem pengajian kitab kuning sudah menerapkan beberapa metode sebagai penunjang kegiatan pembelajaran seperti, metode sorogan, bandongan, muhadharah dan lain-lain sebagainya.

Peneliti juga melakukan wawancara terkait penerapan metode Amtsilati, dalam hal ini Menurut penuturan dari UstadzAkhma Kanzul Fikri:

"Metode Amtsilati diterapkan di pondok pesantren Al-Aqobah sejak tahun 2006 sampai saat ini karena kami anggap metode yang paling mudah untuk mempelajari kitab kuning.Kitab Amtsilati yang terdiri lima jilid dan kitab Khulashahyang merupakan ringkasan dari kitab Al-fiyyah ini membahas ilmu Nahwudan ilmu Sharaf tingkatandasar dan menengah. Amtsilatiberbeda dengan kitab nahwu dan kitab sharaf lain yang tingkatannya menengah ke atas seperti kitab Juruniyyah yang banyak membahas definisi sedangkanAmtsilatitidak membahas definisi tetapi langsung memberi contoh. Selain itu metode Amtsilati ini juga kami terapkan karena menurut kami merupakan solusi atas permasalahan perkembangan zaman yang membedakan tuntutan santri dulu yang mondoknya bertahun-tahun dan hanya ngaji saja sedangkan santri saat ini disamping harus bisa ngaji juga harus sekolah. ${ }^{15}$

Menurut Ustadz Nasrullah:

Metode Amtsilati diterapkan dan ditekankan pada kelas 7 SMPdan kelas 10 SMApada jenjang dan kategori kemampuan yang berbeda-beda, karena masih santri baru yang belum bisa mulai membaca, menulis dan mengetahui nahwu sharafnya dan juga harus ada pelajaran yang dihafalakan. Maka dalam kegiatan pembelajaran dengan menggunakan metode ini kebanyakan dari santri dituntut untuk menghafalkan kitab khulashah kemudian mendengarkan dengan seksama penjelasan kitab amtsilati juz 1-5 dari ustadz, namun untuk tingkat kepahaman masih perlu dipertanyakan, karena jika ustadz bertanya kepada santrinya, santri akan cenderung hanya hafal tetapi terkadang belum begitu faham dengan yang mereka hafalkan. ${ }^{16}$

Menurut penuturan dari salah satu Ustadz pondok pesantren al-Aqobah Kwaron Diwek

Jombang. Ustadz Imam Fauzi :

Kegiatan pembelajarankitab kuning dengan menerapkan metode Amtsilati yang telah diselesaikan di tahun pertama ditidaklajuti di tahun kedua yakni metode sorogan ini sudah terlaksana dengan baik karena seorang ustadz mampu berkomunikasi, dan selalu mengawasi perkembangan kemampuan baik peningkatan maupun penurunan membaca kitab kuning dengan baik dengan santrinya serta ustadz bisa memotivasi santri agar mengikuti pembelajaran dengan baik. Sehingga santripun akan mudah memahami penjelasan yang disampaikan oleh ustasdz. Kemudian disinilah transfer ilmu akan terjadi dengan baik.

\footnotetext{
${ }^{14}$ Arif Wicaksono, Observasi (Pondok Pesantren Al-Aqobah, 23Agustus 2017).

${ }^{15}$ Akhmad Kanzul Fikri, Wawancara (Pondok Pesantren Al-Aqobah, 23Agustus 2017).

${ }^{16}$ Ustadz Nasrul, Wawancara(Pondok Pesantren Al-Aqobah, 23Agustus 2017).
} 
Walaupun mungkin ada beberapa santri yang kurang kepemahamannya. Karena tingkat kepahaman setiap santri tidaklah sama sehingga ustadz harus sering-sering mengulang pelajaran, terutama selalu menerapkan nahwu dan sharaf yang telah mereka hafalkan di tahun pertama supaya tidak lupa. ${ }^{17}$

Menurut penuturan Muhammad Abul Fadhilah kelas 9 SMP santri pondok pesantren alAqobah Kwaron Diwek Jombang: Untuk memantapkan metode Amtsilati yang telah dituntaskan di tahun pertama maka ditindaklajuti dengan metode Sorogan di tahun kedua ketika kelas 8 SMP serta selalu ditanya kembali nahwu sharaf dan dalilnya yang telah dihafalkan dikelas 7 pada tahun pertama, hal ini dilakukan supaya santri terbiasa membaca kitab kuning . Kemudian di tahun ketiga ketika kelas 9 SMP para santri menindak lanjuti nahwu sharaf yang telah dihafal dan di fahami dengan mengaji kitab yang lebih tinggi menggunakan metode Bandongan, sorogan dan tanyajawab kepada kiyai dan ustadz senior untuk menambah keilmuan mereka dan para santri dilatih supaya bisa menyampaikan apa yang telah dia fahami ${ }^{18}$.

Dari uraian narasumber di atas, metode Amtsilatiyang diterapkan pada proses pembelajaran Santri di pondok pesantren al-Aqobah Kwaron Diwek Jombang kendatinya sudah berjalan dengan baik, hal ini di dukung dengan kemampuan seorang ustadz mampu menguasai metode dan materi pembelajaran dengan baik disamping itu seorang ustadz harus mampu berkomunikasi dengan santrinya dan mampu memberikan motivasi kepada santri, sehingga santri akan lebih bersemangat dalam mengikuti kegiatan pembelajaran. Diawal pembelajaran ustadz harus sering-sering mengulang pembelajaran yang disampaikan kemarin dan pada akhir pembelajaran ustadz harus bertanya hafalan dan kepahaman dari setiap santri kemudian memberikan kesimpulan pada pembelajaran tersebut.

Untuk santri, penerapan metode sorogan dalam kegiatan pembelajaran akan efektif jika komunikasi santri dan ustadz terjalin dengan baik kemudian, santri benar mendengankan dan memaknai kitabnya, menanyakan yang belum paham pada ustadz atau teman-temannya yang sudah paham. Dan apabila metode tersebut didasari dengan hafalan dan pemahaman nahwu dan sharaf akan sangat membantu dalam kegiatan pembelajaran.

Sesuai dengan pengamatan yang dilakukan oleh peneliti penggunaan metode Amtsilatijuga terdapat metode pendukung lain yang bisa menambah daya pacu dan mempercepat kemampuan santri dalam mempelajari kitab kuning, diantaranya dikombinasikan dengan menggunakan metode halaqoh, bandongan, dan muhadharah. Dalam pelaksanaannya terbilang sudah efektif untuk mengajar santri agar bisa membaca kitab kuning, karena disini metode

\footnotetext{
${ }^{17}$ Imam Fauzi, Wawancara (Pondok Pesantren Al-Aqobah, 23Agustus 2017).

${ }^{18}$ Muhammad Abul Fadhilah, Wawancara(Pondok Pesantren Al-Aqobah, 23Agustus 2017).
} 
Amtsilati tidak hanya di jam kegiatan saja tapi juga diluar jam tersebut yang satu kelompok terdiri dari teman sekamar yang lebih mengerti jadi akan menuntut santri untuk bisa mandiri dalam lebih aktif dalam proses belajar membaca kitabnya.

Dari pemaparan data diatas untuk penerapan metode Amtsilati menggunakan metode sorogan, bandongan, diskusi, hafalan, muhadharah dan musyawaroh sudah terbilang efektif karena materi yang dipelajari sering diulang-ulang setiap hari dan setiap santri mempunyai kewajiban untuk membaca kitab kuning sesuai dengan kitab yang dikuasainya dan didiskusikan bersama apabila ada kata atau nahwu sharaf yang belum diketahui oleh teman-temannya. Adapun evaluasi bimbingan membaca kitab dengan menggunakan metode Amtsilati di pondok pesantren al-Aqobah Kwaron Diwek Jombang peneliti mewawancarai ketua yayasan sekaligus ustadz Pondok Pesantren al-Aqobah Kwaron Diwek Jombang. Menurut penuturan Ustadz Akhmad Kanzul Fikri:

Untuk mengevaluasi metode Amtsilati yang diterapkan di pondok pesantren al-Aqobah Kwaron Diwek Jombang menggunakan dua macam tes yakni, yang pertama tes lisan yang dibagi tes hafalan kitab khulashahdan tes membaca kitab gundul. Yang kedua menggunakan tes tulis dilaksanakan di akhir tahun. Sementara untuk tes lisan selain diadakan di pondok sebagai persyaratan mengikuti wisuda, kami adakan juga tes lisan setiap tahun ketika prosesi wisuda santri yang telah merampungkan metode Amtsilati pada tahun pertama mereka di tes di hadapan para undangan dengan cara diberi pertanyaan seputar nahwu dan sharaf kemudian santri menjawab serta menunjukkan dalilnya. disamping itu juga ketika wali santri mengunjungi anaknya kami tes di hadapan orang tua mereka supaya orang tua mereka mengetahui kemampuan anaknya. Hal ini kita adakan supaya ketika santri sudah mulai jenuh bisa bersemangat kembali untuk belajar ${ }^{19}$. Berdasarkan observasi peneliti hal demikian sangat memungkikan untuk dilakukan karena setiap hari santri Pondok Pesantren al-Aqobah Kwaron Diwek Jombang sudah selalu membaca berulang-ulang kitab Khulashah yang sudah mereka hafalkan sebagai dalil nahwu dan sharaf.

Dalam mengimplementasikan metode Amtsilati pada Santri Pondok Pesantren AlAqobah Kwaron Diwek Jombang kyai sangat menjunjung tinggi nilai ilmu pendidikan secara utuh dan tidak mengenal istilah diktonomi ilmu pengatahuan antara ilmu umum dan ilmu agama. Anak yang dilahirkan itu mempunyai potensi baik dalam dirinya, tinggal kita para pendidik bisa menemukan dan mengarahkan potensi tersebut. Di sekolah yang ada dibawah naungan pondok pesantren Al-Aqobah Kwaron Diwek Jombang itu diantaranya SMP dan SMA

\footnotetext{
${ }^{19}$ Akhmad Kanzul Fikri, Wawancara (Pondok Pesantren Al-Aqobah, 23Agustus 2017).
} 
yang semua siswanya itu diharuskan bisa membaca kitab kuning dengan metode Amsilati yang sudah beberapa tahun digunakan untuk menjadi acuan semua santri. Karena dalam realitanya hari ini, santri itu dalam 3 tahun dituntut untuk bisa mengaji kitab kuning, penelitian juga bisa bahkan nilai ujian nasional juga bagus. Karenanya di pondok pesantren Al-Aqobah Kwaron Diwek Jombang sendiri itu tidak mencampur adukan antara kurikulum pondok dengan kurikulum nasional yang ada di sekolah. Misalkan santri di pondok ngaji kitab Bulughul marom dan di sekolah juga di ajarkan kitab tersebut, itu dikhawatirkan akan adanya tumpang tindih dan nantinya siswa yang juga tinggal di pondok tidak meremehkan mata pelajaran misalnya B. Inggris, matematika dan mata pelajaran lainnya. Pernyataan ini sejalan dengan Hasan yang mengemukakan bahwa, posisi kurikulum dalam proses pendidikan menentukan apa yang seharusnya menjadi tolak ukur keberhasilan kurikulum sebagai bagian dari keberhasilan pendidikan. $^{20}$

Metode Amtsilati diselesaikan hanya dalam waktu satu tahun dengan menggunakan metode tiqror (di ulang-ulang/mengulang-ngulang). Alasan memilih metode tersebut karena sesuatu yang diulang-ulang seperti tahlilan, yasinan, dll semakin sering dilakukan maka tidak terasa bisa hafal dengan sendirinya.Misalkan satu hari lima nadzom setiap selesai shalat maktubah dibaca mereka dalam satu hari membaca lima nadzom tersebut lima kali kalau dilakukan (waktu tiga tahun) secara terus menerus para santri bisa hafal semua nadzom yang berjumlah 190 nadzom dari kitab khulashah tanpa merasa terbebani. Maka pada tahun pertama santri sudah hafal semua nadzom khulashah tersebut. Khulashah tersebut adalah ringkasan Kitab Al-Fiyyah Ibnu Malik yang merupakan adikarya yang luhur dan monumental Imam Ibnu Malik Al-Andalusia yang berisi pokok-pokok semua ilmu nahwu dan sharaf, kitab ini sudah berusia lama dan sangat terkenal dan populer dikalangan pesantren dan dipergunakan oleh para ulama, santri dan pelajar madrasah mulai tingkat tsanawiyyah, aliyyah bahkan perguruan tinggi $^{21}$.Prinsip yang digunakan sama dengan halnya menghafal kitab khulashah dan memahami kitab amtsilatiyaitu enjoy dan santai, di Pondok Al-Aqobah Kwaron Diwek Jombang sendiri menggunakan metode enjoy full learning karena aspek psikologis itu membantu para santri menghapal lebih mudah.

Hal ini sesuai dengan UU RI No.20 Th 2003 pasal 40 menyatakan bahwa seorang pendidik berkewajiban untuk menciptakan suasana pendidikan yang bermakna, menyenangkan, kreatif, dinamis dan dialogis. Menindak lanjuti metode Amtsilati yang telah dihafalkan dan

\footnotetext{
${ }^{20}$ Jurnal At-Ta'dib Unhasy 2013 hal.3

${ }^{21}$ M. Sholihuddin Shofwan. Maqoshid an-nahwiyyah.jombang.Darul Hikmah.2002 hal.3
} 
difahami maka pada tahun kedua digunakan untuk latihan menerapkan nahwu dan sharaf dengan membaca kitab kuning dengan metode sorogan yang dilaksanakan setiap ba'da magrib. Dengan cara demikian:

Ustadz memberi salam dilanjutkan membaca do'a/surah al-Fatihah sebagai permulaan belajar, sebagaimana tradisi yang berlaku di pesantren. Kali ini santri membaca jika diperlukan santri secara bergantian membaca dan menerjemahkan meteri secara sambung-menyambung (tidak mengulangi bacaaan temannya lagi, kecuali jika amat diperlukan, semisal terlalu banyak santri yang belum bisa) dengan disimak oleh ustadz dan semua santri.

Ustadz menegur santri bila ada yang keliru dalam membaca, memberi makna, mentarkib, atau menerjemahkan dan memberi kesempatan kepada santri lain untuk membetulkan sebagai rasa tanggungjawab dia menyimak bacaan temannya (ustadz tidak secara langsung membetulkanya, kecuali ia diperlukan) agar ia juga lebih merasa dihargai bila mampu membetulkan temannya dan memotifasi teman yang lain yang belum bisa untuk lebih mempersiapkan diri. Ustadz sering memberi satu atau dua pertanyaan nahwu dan Sharaf yang beserta dalilnya sesuai dengan kemampuan santri. Ketika dia membaca walaupun sudah benar bacaanya hal ini supaya santri mengetahui manfaat mempelajari nahwu dan Shorof dan manfaatnya dalam memahami kitab kuning, bila belum bisa menjawab agar memberi kesempatan pada teman yang lain untuk menjawab

Ustadz menerjemah ulang bila diperlukan dan menerangkan materi yang telah dibaca oleh santri dan diteruskan dengan tanyajawab/diskusi dan diakhiri belajar secara bersamasama. $^{22}$ Hal ini sesuai dengan pendapat Sindu Galba bahwa penerapan metode sorogan itu adalah para santri dengan berbekal kitab yang ingin didalaminya membaca di hadapan ustadz untuk mendapat kebenaran bacaan dan kejelasan makna. Proses ini dilakukan oleh ustadz secara bergantian diantara sejumlah santri. ${ }^{23}$

Tahun ketiga para santri mulai belajar memahami kandungan kitab kuning dengan mengaji kepada kyai dan ustadz senior menggunakan metode bandongan, sorogan dan tanyajawab. Pada tahap ini kyai memabacakan kitab beserta maknanya beserta menjelaskan isi kitab dan sesekali kyai atau ustadz bertanya kepada santri tentang nahwu dan sharaf dan menyebutkan dalilnya. Kesempatan kali ini kyai atau ustadz menggunakan makna jawa yang terkadang tidak ada terjemahannya di kamus. Hal ini sesuaidengan yang dituturkan oleh A. Mubarok Yasin banwa menurut catatan sejarah orang yang pertama kali menggunakan makna

\footnotetext{
${ }^{22}$ Jurnal MASS Aliyah Tebuireng

${ }^{23}$ Sindu Galba, PesantrenSebagaiWadahKomunikasi, Jakarta: RinekaCipta, 1995.Hal. 13-16.
} 
gundol jawa. Konon, sunan ampel memilih bahasa jawa sebagai bahasa kitab kuning karena bahasa jawa memiliki perbendaharaan kosa kata yang lengkap. ${ }^{24}$

\section{Kendala dan Solusi}

Dalam mengimplementasikan metode Amtsilati dalam mempercepat kemampuan membaca kitab kuning di Pondok Pesantren al-Aqobah Kwaron Diwek Jombang sedikit banyaknya pasti dipengaruhi beberapa faktor baik internal maupun eksternal di sekelilingnya. Faktor-faktor tersebut ada yang menjadi faktor pendukung dan ada juga yang menjadi faktor penghambat diantara lain adalah sebagai berikut:

Kendala implementasikan metode Amtsilati dalam mempercepat kemampuan membaca kitab kuning di Pondok Pesantren al-Aqobah Kwaron Diwek Jombang adalah kejenuhan dan kesulitan untuk menghafal dan memahami serta menerapkan metode Amtsilati. karena mereka juga dituntut untuk mempelajari ilmu-ilmu umum sebagai syarat kelulusan ujian negara juga mereka harus mempelajari kitab kuning sebagai wujud penajagaan ilmu kuno yang diwariskan oleh para ulama sebagai prinsip utama Pondok Pesantren al-Aqobah Kwaron Diwek Jombang . Sedangkan syarat yang harus mereka penuhi supaya bisa membaca kitab kuning mereka harus memahami nahwu, sharafnya terlebih dahulu.

Solusi implementasikan metode Amtsilati dalam mempercepat kemampuan membaca kitab kuning di Pondok Pesantren al-Aqobah Kwaron Diwek Jombang adalah tawaran belajar nahwu dan sharaf dengan mudah dan menyenangkan. Pada kesempatan ini peneliti mewawancarai Ustadz Akhmad Kanzul Fikrisebagai ketua yayasan serta ustadz diPondok Pesantren al-Aqobah Kwaron Diwek Jombang:

Di zaman sekarang sudah banyak kemajuan teknologi sehingga banyak lahir ilmu-ilmu baru yang dapat mempengaruhi semangat santri dalam mempelajari kitab kuning yang notabennya adalah materi pelajaran kuno, sulit dan membosankan dibanding materi pelajaran umum. Tetapi para santri memang padarnya harus bisa mengaji meskipun mereka juga wajib mempelajari ilmu umum, ilmu yang baru karena nanti ketika pulang tidak semua jadi kiyai, maka kami tekankkan kepada para santri supaya belajar ilmu umum juga belajar ilmu agama. Supaya jika jadi ilmuan maka mereka jadi ilmuan yang islami, jika mereka jadi usahawan jadi usahawan yang islami. Oleh sebab itulah kami menawarkan metode mudah dan cepat membaca kitab kuning yakni metode amtsilatiagar para santri tidak takut sebelum mengaji, kami selalu

${ }^{24}$ A. Mubarok Yasin....... hal.21 
menanamkan mereka bahwa belajar nahwu sharaf dengan metode amtsilati itu sangat mudah dan menyenangkan. ${ }^{25}$

Berdasarkan observasi peneliti ada banyak kendala santri yang beragam, dilihat dari jenjang kelas yang sama namun pengalaman belajar kitab kuning yang berbda dan terdapat kelompok yang masih sangat minim sekali pengetahuan mengenai baca kitab yang benar. Dan dengan kendala tersebut dari beberapa guru dan salah satunya cara yang paling baik adalah solusinya dengan santri kelas akhir yang sudah mahir dalam memahami kitab Amtsilati menerangkan kepada adik kelasnya dengan diawasi oleh sang guru sebagai rujukan sekaligus sebagai pembimbing dalam masalah kata dan makna yang perlu dibenahi dalam kitab kuning. Dan dengan solusi lain, metode amtsilati sudah efektif karena sudah didukung dengan metode lain yakni Sorogan, Bandongan dan tanyajawab dan kegiatan di luar jam kegiatan seperti muhadharah yang dilaksanakan setiap malam minggu serta tak kalah penting adalah kegiatan tambahan menggunakan metode seperti halaqoh, diskusi, hafalan, ceramah dan lain sebagainya, dengan adanya kegiatan tambahan tersebut, kemampuan santri akan lebih bagus karena masih menambah untuk capaian kemampuan membaca kitab kuning. ${ }^{26}$

Hal ini diperkuat oleh pernyataan Ustadz Nasrullah: Ada sedikit kendala yang kami hadapi dalam pembelajaran kitab kuning dengan metode ini yakni dari sisi siswanya.Tidak semua santri sudah hafal dan mahir benar membaca kitab kuning, jadi kita beri kegiatan tambahan yakni dengan kegiatan Muhadharah atau mengkombinasikan metode tersebut dengan metode halaqoh, diskusi, hafalan, dan ceramah. ${ }^{27}$ Kemudian ditambahkan oleh Qodir santri kelas 12 SMA menuturkan bahwa: Salah satu faktor penghambat santri untuk mempelajari kitab kuning menggunakan metode Amtsilati adalah kurangnya kepercayaan diri oleh karena itu sesekali mereka belajar dan berdiskusi dengan santri yang kelas 12 SMA. $^{28}$

Dalam mengimplementasikan metode Amtsilati di Pondok Pesantren al-Aqobah Kwaron Diwek Jombang sedikit banyaknya pasti dipengaruhi beberapa faktor baik internal maupun eksternal di sekelilingnya. Faktor-faktor tersebut ada yang menjadi faktor pendukung dan ada juga yang menjadi faktor penghambat diantara lain adalah sebagai berikut. Pertama, kendala implementasikan metode Amtsilati dalam mempercepat kemampuan membaca kitab kuning di Pondok Pesantren al-Aqobah Kwaron Diwek Jombang adalah kejenuhan dan kesulitan untuk menghafal dan memahami serta menerapkan metode Amtsilati. Mereka juga

\footnotetext{
${ }^{25}$ Akhmad Kanzul Fikri, Wawancara (Pondok Pesantren Al-Aqobah, 23Agustus 2017).

${ }^{26}$ Arif Wicaksono, Observasi (Pondok Pesantren Al-Aqobah, 23Agustus 2017).

${ }^{27}$ Ustadz Nasrullah, Wawancara, (Pondok Pesantren Al-Aqobah, 23Agustus 2017).

${ }^{28}$ Qodir, Wawancara, (Pondok Pesantren Al-Aqobah, 23Agustus 2017).
} 
dituntut untuk mempelajari ilmu-ilmu umum sebagai syarat kelulusan ujian negara juga mereka harus mempelajari kitab kuning sebagai wujud penajagaan ilmu kuno yang diwariskan oleh para ulama sebagai prinsip utama Pondok Pesantren al-Aqobah Kwaron Diwek Jombang . Sedangkan syarat yang harus mereka penuhi supaya bisa membaca kitab kuning mereka harus memahami nahwu, sharafnya terlebih dahulu. Solusi dari kendala adalah belajar nahwu dan sharaf dengan mudah dan menyenangkan. Pembelajaran menyenangkan ini dikemas dalam bentuk penambahan jam belajar yang dipimpin oleh santri kelas akhir yang sudah mahir dalam memahami kitab Amtsilati.

Santri kelas akhir yang sudah mahir menerangkan kepada adik kelasnya dengan diawasi oleh sang guru sebagai rujukan sekaligus sebagai pembimbing dalam masalah kata dan makna yang perlu dibenahi dalam kitab kuning. Dan dengan solusi lain, metode amtsilati sudah efektif karena sudah didukung dengan metode lain yakni Sorogan, Bandongan dan tanyajawab dan kegiatan di luar jam kegiatan seperti muhadharah yang dilaksanakan setiap malam minggu serta tak kalah penting adalah kegiatan tambahan menggunakan metode seperti halaqoh, diskusi, hafalan, ceramah dan lain sebagainya, dengan adanya kegiatan tambahan tersebut, kemampuan santri akan lebih bagus karena masih menambah untuk capaian kemampuan membaca kitab kuning. Intinya adalah para santri selalu diberi motivasi agar selalu semangat. Hal sesuai dengan yang dituturkan oleh slamet bahwa menumbuhkan motivasi sangat berperan pada kemajuan perkembangan peserta didik. Selanjutnya melalui proses belajar. Bila motivasi pendidik tepat dan mengenai sasaran akan meningkatkan kegiatan belajar siswa dengan tujuan yang jelas maka peserta didik akan tekun, giat dan bersemangat. ${ }^{29}$

\section{Kesimpulan}

Penelitian ini menyimpulkan beberapa poin. Pertama, Implementasi Metode Amtsilati untuk mempercepat kemampuan membaca kitab kuning santri di pondok Al-Aqobah Kwaron Diwek Jombang adalah melalui pemetaan sebagai berikut: a) Tahun pertama menghafalkan qaidah ilmu nahwu dan ilmu sharaf dan memahami lima jilid kitab Amtsilati; b) Tahun kedua mengimplementasikan metode Amtsilati ketika membaca kitab yang telah ditentukan oleh ustadz; c) Tahun ketiga membaca, memahami kandungan kitab kuning dengan acuan metode Amtsilati. Kedua, Kendala dan solusi dalam implementasi metode amtsilati untuk mempercepat kemampuan membaca kitab kuning di pondok Al-Aqobah Kwaron Diwek Jombang adalah Kendala para santri mengalami kejenuhan ketika menghafal dan memahami metode Amtsilati

\footnotetext{
${ }^{29}$ Jurnal at-ta'dib Unhasy 2015, hal 86
} 
karena pengalaman santri yang berbeda sebelum mondok dan belajar kitab kuning. Solusinya adalah penambahan latihan supaya yang masih tertinggal materi bisa menyusul yang sudah faham memberi pengajaran kepada yang belum bisa. 


\section{Referensi}

Al-Amin, H. (2015). Emosi Sufistik Dalam Tafsir Ishari: Studi atas Tafsir Lata> if al-Isha> ra> t Karya al-Qushairi. Disertasi, UIN SyarifHidayatullah Jakarta.

Amin, H. A. (2021). GUARDIANS CONCEPT IN QUR'AN PERSPECTIVE . SHAKHSIYAH BURHANIYAH: Jurnal Penelitian Hukum Islam,6(1), 95 - 114. https://doi.org/10.33752/sbjphi.v6i1.1642

Al Amin, H. (2016). Tafsir Sufi Lataâ€TM if al-Isyarat. SUHUF, 9(1), 59-77.

Departemen Agama RI. 2003. Pondok Pesantren dan Madrasah Diniyah. Jakarta: PT Gramedia

Dhofier Zamakhsyari. 2011. Tradisi Pesantren. Jakarta : LPEES

Durkheim Emile. 1990. Pendidikan Moral: Suatu Studi Teori dan Aplikasi Sosiologi Pendidikan. Jakarta: Erlangga

Haedari Amin dan Ishom El-Saha. 2008. Peningkatan Mutu Terpadu Pesantren dan Madrasah Diniyah. Jakarta: Diva Pustaka Cet. 3.

Haedari Amin dkk,. 2008. Masa Depan Pesantren: Dalam Tantangan Modernitas dan Tantangan Komplesitas Global, Jakarta: Diva Pustaka 2008.

Indrakusuma Amier Daien. 1973. Pengantar Ilmu Pendidikan. Surabaya: Usaha Nasional

Lewis Ramon. 1997. In The Dicipline Dilemma, Control, Management, Influence, Australian Council for Educational Research. Yogyakarta: Gloria Grafa

Makmun Abid Syamsudin dan Udin Saefudin Sa'ud 2006, Perencanaan Pendidikan Suatu Pendekatan Komprehensif, Bandung;Remaja Rosdakarya,

Masyhud Sulthon dan Khusnurridlo. 2003. Manajemen Pondok Pesantren. Jakarta: Diva Pustaka

MU YAPPI, 2008. Manajemen Pengembangan Pondok Pesantren. Jakarta: Media Nusantara

Mastuhu. 1994. Dinamika Sitem Pendidikan Pesantren, Jakarta : INIS

Hidayat, Komaruddin. 2016. Dari Pesantren Untuk Dunia. Jakata: PPIM

Mardiyah, 2015. Kepemimpinan Kiyai Dalam Memelihara Budaya Organisasi. Malang : Aditiyah Media Publishing

Muhammad, Husein. 1999. “Kontekstualisasi Kitab Kuning; Tradisi Kajian Dan Metode Pengajaran,” Bandung : Pustaka Hidayat

Oktavia, Lanny. 2014. Pendidikan Karakter Berbasis Tradisi Pesantren. Jakata : Rumah Kitab 